\title{
MANAGEMENT OF RHEUMATIC CHOREA
}

\section{An observational study}

\author{
Alexandra Prufer de Queiroz Campos Araújo ${ }^{1}$, \\ Paula Assunção Brito Pádua², Heber Souza Maia Filho²
}

\begin{abstract}
Background: Rheumatic chorea (RC) has recently been linked to an antibody-mediated immune mechanism. Objective/Method: To verify if this knowledge reflected in management changes we conceived a descriptive study. Results: The medical charts of 20 children (13 females) aged 6 to 12 years (mean 8 years), diagnosed as RC from June 1996 to June 1999, were reviewed. All patients received some medical treatment. Haloperidol was the most prescribed medication (15 patients - $75 \%$ ). Sulpiride, diazepam and valproate were also used as symptomatic treatment. Imune-modulating therapy with prednisone was prescribed for seven children. The shortest course of chorea (16 days) occurred in a patient treated with prednisone. Conclusion: Prednisone has been prescribed for rheumatic chorea besides the traditional symptomatic approach. A great variety of antichoreic drugs are being employed.
\end{abstract}

KEY WORDS: chorea, rheumatic fever, therapy, prognosis.

\begin{abstract}
Conduta na coréia reumática: um estudo observacional
RESUMO - Fundamentos: A patogenia da coréia reumática relaciona-se a um mecanismo imunomediado. Objetivos/Métodos: A fim de verificar se este conhecimento resultou em mudanças na terapêutica desta doença, elaborou-se um estudo descritivo. Resultados: Foram revistos os prontuários de 20 crianças (13 meninas) entre 6 e 12 anos de idade (média 8 anos), com diagnóstico de coréia reumática realizado entre Junho de 1996 e Junho de 1999. Todos pacientes utilizaram algum tipo de medicação. Haloperidol foi a substância mais prescrita (15 pacientes - 75 \%). Sulpiride, diazepam e ácido valpróico foram também utilizados. Tratamento imunomodulador com prednisona foi prescrito para sete crianças. 0 paciente com o menor tempo de evolução de coréia (16 dias) usou prednisona. Conclusão: Observa-se um emprego mais variado de drogas sintomáticas. Além do tratamento convencional com sintomáticos, verifica-se o uso de prednisona na coréia reumática.
\end{abstract}

PALAVRAS-CHAVE: coréia, febre reumática, tratamento, prognóstico.

Sydenham's chorea, or rheumatic chorea (RC), one of the major diagnostic criteria for rheumatic disease, is the most common acquired chorea during childhood. Characterized as an involuntary, non-stereotyped, arrhythmic and purposeless movement, it may be associated with other neurological abnormalities as hypotonia and behavioral disorders ${ }^{1}$. Chorea in this setting is often considered a benign self-limiting condition ${ }^{2}$.

The entire pathogeneses is not known. A link between the group A beta-haemolytic streptococcus through an antibody-mediated immune response targeting the basal ganglia has been described ${ }^{3}$. Therefore, treatment with immunomodulators seems justified.
To verify if the acquired knowledge on the pathogeneses reflected in management changes of recently diagnosed RC cases, we conducted a descriptive cross-sectional study in a pediatric teaching institution.

\section{METHOD}

The Instituto de Puericultura e Pediatria Martagão Gesteira (IPPMG) is a pediatric hospital affiliated with the Federal University of Rio de Janeiro (UFRJ). We were able to list all patients diagnosed as chorea or rheumatic disease from June 1996 through June 1999, with the help of a coding system list of every day's out-patient clinic. We included patients confirmed as RC ${ }^{4}$, up to 16 years of age, seen during their acute episode of chorea and followed at least for three subsequent visits in our hospital.

Serviço de Neurologia, Instituto de Puericultura e Pediatria Martagão Gesteira (IPPMG), Universidade Federal do Rio de Janeiro (UFRJ), Rio de Janeiro RJ, Brasil: ${ }^{1} \mathrm{PhD}$, Associate Professor; ${ }^{2} \mathrm{MD}$, Resident in Neuropediatrics.

Received 3 August 2001, received in final form 22 October 2001. Accepted 29 October 2001. 
Children with other causes of chorea (congenital, hereditary, drug-induced, metabolic, endocrinological, infectious, or other autoimmune conditions) were excluded. Information was gathered from medical charts, data collected in Epiinfo 6 software and summarized using descriptive statistics.

The Review Board of the Federal University of Rio de Janeiro has approved this study.

\section{RESULTS}

One hundred and eight new cases of rheumatic disease were diagnosed and 24 of these were new chorea cases. Four were not included in this study due to insufficient follow-up. The age range from chorea patients was 6 to 12 years (mean 8 years), with a predominance of the female gender (65\%). The follow-up varied from 4 months to 6 years and 9 months, and most (60\%) were seen in the Neurology Unit. The others were followed by either the Cardiology or Rheumatology Unit.

Most of the patients came to medical care in less than ten days (60\%). In only three, it took more than one month to reach the final diagnosis. All patients received some medical treatment for the chorea and all were prescribed penicillin for prophylaxis of streptococcal infections. Table 1 shows the main clinical features, dividing the seven patients that received prednisone as one of the drugs during treatment, from those that received only symptomatic treatment. Half of the children used more than one drug for chorea. Table 2 shows the order of treat- ment choice in our hospital. It was mainly a symptomatic management of chorea from the start with a predominance of haloperidol over all other drugs. This drug was the first choice of treatment whenever the children were seen by the pediatric cardiologist or rheumatologist. The neurologists prescribed a greater diversity of drugs. Sedation as adverse reaction occurred in a third of those treated with symptomatic drugs.

One patient used prednisone as his first and only treatment, and had the shortest course of chorea. Six other children received prednisone as second or third choice (one after using diazepam, two after haloperidol, one after valproate and sulpiride, two after diazepam and valproate). A third of the children treated with prednisone (15\% of the treated with symptomatics) had chorea duration of less than 3 months.

The overall mean time to resolution of chorea was of 6 months ( 16 days - 22 months). There was no clear correlation between a faster resolution of chorea and a quicker start of the drugs as a whole ( 1 to 60 days for those who became asymptomatic in less than 6 months).

\section{DISCUSSION}

Pathogeneses of RC is nowadays better understood, but few changes in management and outcome are seen. Haloperidol, as a symptomatic controlling agent, is still the drug of choice in our set-

Table 1. Clinical features and treatment options in rheumatic chorea, IPPMG/UFRJ, 1996-1999.

\begin{tabular}{lccc}
\hline & $\begin{array}{c}\text { Prednisone treatment } \\
(\mathrm{n}=7)(\mathrm{n}=13)\end{array}$ & $\begin{array}{c}\text { Symptomatic treatment } \\
(\mathrm{n}=20)\end{array}$ & Total \\
\hline Arthritis & 6 & 4 & 10 \\
Carditis & 3 & 3 & 6 \\
Subcutaneous nodules & 1 & 0 & 1 \\
Emotional lability & 5 & 5 & 10 \\
Severity & 2 & 1 & 3 \\
$\quad$ Unable to walk & 2 & 7 & 9 \\
$\quad$ Admitted to hospital ward & 0 & 4 & 4 \\
Recurrence & & & \\
\hline
\end{tabular}

Table 2.Treatment in rheumatic chorea patients, drug choice and sequential order, IPPMG/UFRJ, 1996-1999.

\begin{tabular}{lccccc}
\hline \multicolumn{5}{c}{ Order } \\
\cline { 2 - 6 } Drug & First choice & $2^{\text {nd }}$ choice & $3^{\text {rd }}$ choice & $4^{\text {th }}$ choice & Total \\
\hline Haloperidol & 12 & 1 & 1 & 1 & 15 \\
Valproate & 2 & 4 & 0 & 1 & 7 \\
Prednisone & 1 & 3 & 3 & 0 & 7 \\
Diazepam & 5 & 0 & 0 & 0 & 5 \\
Sulpiride & 0 & 3 & 0 & 0 & 3 \\
Total & 20 & 11 & 4 & 2 & - \\
\hline
\end{tabular}


ting. Only a few patients (35\%) are given prednisone as a therapy directed to the immune-mediated disorder.

The general features of this series, as the age range and a small higher prevalence of the female patients, compares to previous ones ${ }^{1,5,6}$. Pure chorea was found in $30 \%$ of our patients, and as pointed out before ${ }^{5}$ should always be considered as rheumatic unless supported by other findings (congenital, hereditary, drug-induced, metabolic, endocrinological, infectious, or other autoimmune conditions). The mean time to the resolution of chorea in our population ( 6 months) matches with the natural history of this disease ${ }^{2}$. Only a few patients became unable to walk ( $15 \%)$. This figure compares with those previously found $(0-27 \%)^{1,6}$, as does our recurrence rate $20 \%{ }^{1,5}$.

Although RC is thought as a benign self-limited condition of the central nervous system, the symptoms are long lasting, persistence of chorea may occur in some patients ${ }^{7}$ as well as transitory or residual major motor disability ${ }^{8}$.

Only seven patients in the present study were prescribed prednisone and most of them after failure of symptomatic treatment. Steroids have been shown to be effective in $\mathrm{RC}^{9,10}$. Our results reinforce this notion, since a greater proportion of the children treated with prednisone had a shorter duration of chorea. Nevertheless, only a controlled clinical trial would be able to support the greater effectiveness of steroids over symptomatic treatment.

The rationale for immune modulators is based on the concept that RC is caused by an indolent inflammation of the small vessels in the caudate-putamen complex. The finding of antibodies reacting with brain tissue ${ }^{11,12}$, the increase in IgG levels in cerebrospinal fluid of patients with chorea ${ }^{13}$, and the correlation of the spectroscopy features with the presence of antibodies in the neostriatum and their cytolytic effect ${ }^{14}$ support this concept. Therefore treatment with immune modulators seems justified. Prednisone would be a less expensive approach than intravenous immunoglobulin as suggested by others ${ }^{3}$.

As far as symptomatic treatment is concerned, other drugs have been shown to be effective in controlling the movement disorder, such as valproate ${ }^{15}$, carbamazepine $^{16}$, baclofen ${ }^{17}$, other post-synaptic anti-dopaminergic agents ${ }^{18,19}$, and pre-synaptic dopaminergic antagonists ${ }^{20}$. The maintenance of haloperidol as a main treatment choice appears to result from the absence of controlled trials with those other agents. Nevertheless the possibility of adverse reactions should prompt the use of safer drugs ${ }^{21}$. Although a greater variety of drugs are being using in the treatment of $\mathrm{RC}$, haloperidol is still the most common prescribed drug by non-neurologists. The current guidelines of the Brazilian Society of Pediatrics for treatment of RC in Brazil 22, elaborated by rheumatologists, recommend haloperidol. This seems to be the main reason for the prescription of this drug by the pediatricians. The literature concerning newer treatment options might not have reached the broader spectrum of clinicians that take part in the care of patients with rheumatic disease.

\section{REFERENCES}

1. Swedo SE, Leonard HL, Schapiro MB, et al. Sydenham's chorea: physical and psychological symptoms of St Vitus dance. Pediatrics 1993;91:706-713.

2. Eshel G, Lahat E, Azizi E, Gross B, Aladjem M. Chorea as a manifestation of rheumatic fever: a 30-year survey (1960-1990). Eur J Pediatr 1993;152:645-646.

3. Swedo SE. Sydenham's chorea, a model for childhood autoimmune neuropsychiatric disorders. JAMA 1994;272:1788-1791.

4. Special Writing Group of the Committee on Rheumatic Fever, Endocarditis and Kawasaki Disease of the Council on Cardiovascular Disease in the Young of the American Heart Association. Guidelines for the diagnosis of rheumatic fever. Jones criteria, 1992 update. JAMA 1992;268:2069-2073.

5. Goldenberg J, Ferraz MB, Fonseca AS, et al. Sydenham chorea: clinical and laboratory findings: analysis of 187 cases. Rev Paul Med 1992;110:152-157.

6. Cardoso F, Eduardo C, Silva AP, Mota CC. Chorea in fifty consecutive patients with rheumatic fever. Mov Disord 1997;12:701-703.

7. Gibb WR, Lees AJ, Scadding JW. Persistent rheumatic chorea. Neurology 1985;35:101-102.

8. Bird MT, Palkes H, Prensky AL. A follow-up study of Sydenham's chorea. Neurology 1976;26:601-606.

9. Fritel G, Harpey JP. Indication for corticotherapy in Sydenham's chorea. Clinique (Paris) 1965;60:605-610.

10. Siqueira LC, Oliveira AD. Treatment of Sydenham's chorea with shortterm steroids. Bol Inst Pueric Martagao Gesteira 1965;22:113-116.

11. Abraham S, O'Gorman, M.,Shulman, S. T. Anti-nuclear antibodies in Sydenham's chorea. Adv Exp Med Biol 1997;418:153-156.

12. Bronze MS, Dale JB. Epitopes of streptococcal M proteins that evoke antibodies that cross-react with human brain. J Immunol 1993;151:28202828.

13. Gledhill RF. Selective increase in cerebrospinal fluid immunoglobulin $\mathrm{G}$ in a patient with Sydenham's chorea [letter]. J Neurol Neurosurg Psychiatry 1986;49:602-603.

14. Castillo M, Kwock L, Arbalaez A. Sydenham's chorea: MRI and proton spectroscopy. Neuroradiology 1999;41:943-945.

15. Daoud A S, Zaki M., Shakir R, al-Saleh Q. Effectiveness of sodium valproate in the treatment of Sydenham's chorea. Neurology 1990; 40:1140-1141.

16. Artigas Pallares J, Lorente Hurtado I. Carbamazepine in paroxysmal choreoathetosis in Sydenham's chorea. An Esp Pediatr 1989;30:41-44.

17. Sandyk, R. Sodium valproate and baclofen for Sydenham's chorea [letter]. S Afr Med J 1983;64: 6.

18. Shannon KM, Fenichel GM. Pimozide treatment of Sydenham's chorea. Neurology 1990;40:186

19. Flores Suarez RE, Frati Munari AC, Lopez Sanchez E, Criollos Torres O. Treatment of Sydenham's chorea with perphenazine. Bol Med Hosp Infant Mex 1978;35:569-575.

20. Hawkes CH, Nourse CH. Tetrabenazine in Sydenham's chorea. Br Med J 1977;1:1391-1392.

21. Shields W D, Bray, P F. A danger of haloperidol therapy in children. J Pediatr 1976;88:301-303.

22. Azevedo ECL. Febre reumática. In Oliveira SKF, (coord). Manual de reumatologia pediátrica. Comitê de Reumatologia. Rio de Janeiro: Sociedade Brasileira de Pediatria, 1993:27-33. 